\title{
The Profound Influences of Political Factors in Policy Process in Some Developing Countries - An Overview
}

\author{
Edmore Ntini, (Lecturer) \\ School of Built Environment and Development Studies, University of KwaZulu-Natal, \\ Howard College, Durban, 4041. South Africa \\ Email: eddiemza@gmail.com
}

\section{Doi:10.5901/mjss.2014.v5n23p1995}

\begin{abstract}
This article argues that policy process in some developing countries has been profoundly influenced by political factors. Policy process is a highly contested terrain. Heads of state make a deliberate attempt to use it as a political tool for prolonging their stay in power. Where there are no democratic structures and mechanisms for checking the government, policy process runs the risk of being abused for personal aggrandizement, exploitation of the poor peasantry, suppressing the opposition parties.
\end{abstract}

Keywords: developing countries, participation, policy process, political parties, political elite, political tool, state.

\section{Introduction}

The writer provides a working definition of the state, political factors and policy process. Political leadership as a factor in policy process is analysed in an effort to demonstrate that in developing countries policy process is a political tool. Third World political leaders deliberately confine participation to the few elite/political elite.

\section{Political Factors (The State and Political Parties)}

\subsection{Political party}

Morgan (1981:613-625) and Howard (1980:10-20) view t a political party as an "an organized [political] opinion" or a group of men professing same political doctrine comprising organized bodies with voluntary membership, their concerted energy being employed in the pursuit of political power. Gilchrist (2000: 640) defines a political party as an organized group of citizens who prefer to share the same political views and who by acting as a political unit try to control the government. Gettel (2004:274) points out that a political party consists of a group of citizens more or less organized who act as a political unit and who by the use of their voting power aim to control the government and carry out their general policies. One may note therefore that the term political party refers to more or less an organised group of citizens who act together as a political unit. They share or profess to share the same opinion on public questions and by exercising their voting power towards a common end, seek to obtain the control of the government. Epstein (1967: 127) remarks that a political party is any group seeking to elect governmental officeholders under a given label. Weber (1904-1905) defined a political party as a voluntary organization of propaganda and agitation, seeking to acquire power in order to procure chances for its active militant adherents to realize objectives, aims or personal advantages or both. Maclever (1947: 298) defines a political party as an association organized in support of some principle of policy which by constitutional means it endeavours to make the determinant of government. Duverger (1964: 155) and Lenin (1904: 74) say political parties push for the interests of the people in organizing citizens in enhancing political participation, in decision making, in striving to acquire power, in promoting national interest and in protecting their rights. It is worth noting that political parties have a strong link with composition of the government and that they have a strong influence on the policies of the government in office. Policy process eventually becomes one of the areas political parties contest, monitor closely, differ on issues and contest for public support on the basis of policy. In Zimbabwe the land policy is a sensitive issue as the ruling ZANU-PF party and the opposition MDC parties seem not agreed. There is mistrust on land distribution as a theme on one hand and the process on the other hand. Both are using it to mobilize support. 


\subsection{The state}

Finbarr (2011:1) defines a state as an organisation that exercises legitimate coercion; the organisation that holds a monopoly of force within a territory. McGrew (1992:260) points out that a state is an ensemble or collection of political agent, institutions, organisations, apparatuses and processes that plays an important role in society. He further explains that this ensemble includes politicians, government ministers, civil servants, state bureaucrats and functionaries all attached in one way or another to political parties and the electoral system and processes, the government department and the various government departments. Thomas (1992:124) points out that the state consists of the executive, judicial and legislative. Potter (1992:273) says that it possesses legal sovereignty (rules) over a particular geographical territory and the individuals, groups and resources within it; and it usually has a monopoly over the use of force within its territory and has a legal identity in relation to other states. According to Danziger (1998:106) the state is 'a territorially bound sovereign entity'. Ranny (1987:35-37) provides five requirements of statehood: a particular territory, definite population, a government, formal independence or sovereignty, and a sense of national identity. The state is supposed to have complete authority over a certain area and to be the ultimate source of law within its boundaries. It supposedly has absolute sovereignty and the rules made within the state are not supposed to be able overruled by any other body (Lawson 1997:35-36). Clapham (1996:10) argues that a state is not only a sovereign territory, but must have both territorial and governmental legitimacy.

\section{The Role of the State}

Potter (1992:131) points out that by its nature, the state rules over, and leads and represents society and its citizens. He further says that it controls its own citizens and enters into negotiations and makes bargains and treaties with other countries. The executive, judicial and legislative powers enable it to carry out these roles. Thomas \& Potter (1992:128) point out the legitimacy of the state in contemporary societies depends largely on whether or not it is seen to be representing the material interests and values of all members of society. Potter (1999:133) points out that the state is only one actor in society which fulfills or fails to fulfill its roles with or within the context of other actors in society such as the electorate, organized labour, the corporate world and civil society. One may view the role of the state as to represent, regulate, make choices for and guide society and conduct relations with other societies. However, it must have the authority and power to do so, and this depends largely on whether or not it has legitimacy and is representing its citizen's material interests and values. It is also merely one actor in society, albeit an important one, and this has an impact on how well it fulfills its role, or even if it does so at all. To a larger extent, this is what politics is about-the process and institutions through which actors compete for authority and power and use them to achieve particular interests and values in a context of competing interests and values (including those of the state and personnel). Potter (1992:274) and Thomas (1992:132-133) concur that the state can and does three possible roles in development. These roles are not necessarily mutually exclusive, in that the same state can (perhaps at different times and under various conditions) engage in all three. They argue that the state can take direct responsibility for, and be the primary agent of development facilitation and/or make it possible and inhibit and/or be an obstacle to development. Other factors that can affect the state's role in development include the availability of appropriate human, organizational, technological, and environmental and natural resources; and/or its ability to conduct satisfactory relations with other states.

The state merely promotes the material interests of society's economic elites (by pressing local trade unions) and promotes free-market rather than social welfare values, this is likely to anger the non-elite (the people in need of better wages and cheaper health care). In such a case, the state has made a choice that is not representative of the (developmental) interests of all its citizens, would in all likelihood be undermining its legitimacy, and would thus be putting pressure on its ability to regulate and maintain order and stability in society. Thus in turn would probably hamper any developmental initiatives by the state. In short, the state (its elite) chooses a developmental option on the basis of its interpretation of the wishes of its citizenry and the means at its disposal in order to secure its own interests and values (remaining in power). Potter (1992:275) points out that the state negotiates with economic elites and organisations, and its interpretation of their interests and needs, may determine its general economic policy and consequent developmental choices. Wilson (1992:314) points out that the state is a set of competing political agents, institutions and processes that are varied, complex and conflicting agents. Developmental policy is often the outcome of this intra-state competition. Thomas \& Potter (1992:134) argues that it is the complex and competitive political relations within the state and between state and society that determine the state's development options and policies and their implementation and results, and thus development is fundamentally determined by the relation between politics and economics, between the state and the economy. Kauzya (2011:1)) points out that the state plays roles in the following: building capable, intelligent and effective 
states, restoring stability, peace and security including building capacity to prevent, manage and resolve all conflict, Enforcing constitutionalism and the rule of law, Modernizing and strengthening national judicial systems to ensure, accessible and affordable justice for all, Ensuring respect for human rights including protection of the vulnerable, ethnic minorities, women, and children, Promoting popular participation and strengthening institutions of participatory democracy and local governance. Engineering collective action to satisfy the general interest in areas such as law and order, security of person and property, public health, education, service infrastructures or any other areas collectively agreed as critical to the well-being of the population in question. Going beyond the traditional roles, functions and institutional structures of the State such as: strong institutions of governance and the rule of law: credible judicial and legal institutions: effective legal frameworks for economic activity; adequate steering, regulatory and enforcement capacities, respect for human rights and freedoms, provision of basic services, security to eradicate poverty. Promoting a sharp focus on the needs of the poor, intolerance of corruption; transparency and accountability in the management of public affairs; participation by all citizens in the decisions that affect their lives; creation of an enabling environment for the private sector and civil society; promotion of social justice, universal access to quality services and productive assets; creation of an enabling environment for people-centered development; public and private sector partnerships in the promotion of business with emphasis on micro-industries and small and medium size enterprises; access to information; promotion of technological and infrastructure development in fighting poverty. Working with actors in the private and civil society sectors to redefine and agree upon its mission and mandate as well as the challenges these actors are intended to concern themselves with. This leads to the creation of strong collaborative and participatory linkages among government, civil society, private sector and the citizens themselves in the act of governance and public administration. Politics has an integral role to play in policy processes but it is not the only influence on a decision. One may understand politics in policy issues to be incorporating the interactions of people, institutions, viewpoints, priorities, models, participation governance, power, authority, consent, consultations and responses. Every group involved in a policy process plays politics: Heads of State and ministers, the executive bureaucracy, legislators, societal interests, business interests, the military, labour organizations, the media and religious elites (Turner and Hulme 1997:77) and (Grindle and Thomas 1991:59, 67). The dictionary meaning of the adjective "political" is - "of or concerning the state or its government or public affairs generally" (Fowler and Fowler 1990: 922). Whilst politics refers to interactions, political factors refer to matters of governance, matters to do with ruling a country, running the political shore in a state or regime. It is the nature of governance and its approach to national matters that we are interested in, in this work. George (2004; 4) summarizes the state's and government's organizational and functional duties as to manage political, social and economic processes geared toward development.

\section{Policy Process}

Egulu and Ebanyat (2000:6) define a policy as the means or guidelines set by a group of people/institutions to achieve a goal or solve a problem through a define set of activities and involving consensus. Dye (1995:3 - 4) views public policy as whatever governments choose to do or not to do, the authoritative allocation of values for the whole society and a projected programme of goals, values, and practices for they decide is good for the nation. Fox and Meyer (1995: 107) define policy as authoritative statements made by legitimate public institutions about the way in which they propose to deal with policy problems. Anderson (1997:9) calls it a proposed course of action of a person, group, or government within a given environment providing obstacles and opportunities which the policy was proposed to utilize and overcome in an effort to reach a goal or realize an objective. Ranney (1986:7) defines policy as a declaration and implementation of interest. Dye (1987:3) points out that policy consists of courses or patterns of action by governmental officials in the enactment of law, decisions relating to its implementation, enforcement and the feedback from part of the policy. Ealau and Prewitt (1973:465) call policy a standing decision - as what governments actually do for example protecting the environment, regulating trade, controlling the money supply or inflation and in general supplying public services. It therefore sounds convincing that policy process is a complex set of events that determine what actions governments will take, what effects those actions will have on social conditions and how those actions can be altered if they produce undesirable outcomes. Political factors have a part to play in policy process just as do social, economic and even international factors. According to Turner and Hulme (1997:57-58) policy is about power and thus policy process is an intensely contested political matter.

\section{Political Leadership in Policy Issues}

Turner and Hulme (1997:57) point out that policy process in developing countries is a field of contest in which 
governments endeavour to legitimate their hold on power with opposing forces denigrating the same policies to justify their claim for office. "Most third World regimes are characterized by lack of much political participation; thereby confining policy-making activity to a narrow circle" (Gulhati 1990: 1147, 1148). Turner and Hulme (1997:70;) contend that the typical contemporary regime particularly in Sub Saharan Africa has revolved around the person of the ruler. As a result Turner and Hulme (1997:70) observe that the level of popular participation in policy making is lower in developing countries compared to OECD countries. There are fewer participants and official channels of participation are restricted. Gulhati (1991:1148) describes the regimes as non-institutional and authoritarian, using patronage and coercion to secure compliance, patriotism and ideology giving way to factional struggles and uncertainty. Turner and Hulme (1997:70) have the same view as they note that policy circles are narrow as participation is squeezed out leading to the use of nondemocratic forms of mobilizing power inclusive of violence to challenge the government. The person of the ruler and the extent to which he allows for participation in national policy issues in exemplified by former presidents Kenneth Kaunda (Zambia), the late Kamuzu Banda, the late Idi Amin of Uganda and Robert Mugabe. These have used repression, patron-client ties that bind leaders and followers, co-option and statutory instruments to influence policy processes in their respective states. Turner and Hulme (1997:70) write of Kenneth Kaunda of Zambia allowing for parliamentary debates, letting critical commentaries appear in the media and allowing the presence of conflicts of policy in cabinet and the bureaucracy. At the end Kenneth Kaunda would act as principal arbiter of disputes, overruling cabinet or ignoring it. It is such decisions by a State head that influenced policy process in Zambia as policy would easily be thrown out or ignored. Whether policy would be passed or not in Zambia, it rested on none other than Kenneth Kaunda. In Third World nations, the person of the state head determines the existence of policy or not and whether it should be implemented or not. Bigsten and Kayizzi-Mugerwa (2000:11) state that the MMD changed the constitution to bar Kaunda from running in future elections. A coup attempt in 1997 saw the Chiluba government re-imposing the state of emergency and placing former president Kaunda under house arrest. Ranker, van de Walle, and Mulaisho (1999:35), Bigsten and KayizziMugerwa (2000:12) observe that the conduct of elections proved that the Chiluba government was willing to compromise the rule of law, was intolerant of criticism and willing to exploit its majority position and control of government resources to undermine its opponents. Bigsten and Kayizzi-Mugerwa (2000:12) indicate that other signs of more autocratic approaches were the possession by the President of a special account for "charitable donations" - funded directly via the budget and was used to make very visible presidential donations to schools, churches and this was viewed as a purchasing political support. This shows that policy process among other strategies is used to ensure one 's longevity in office. Where no effective mechanisms of ensuring or limiting political tenure such policies are may go unnoticed and most abused.

Turner and Hulme (1997:70-71) observe that Kamuzu Banda (Malawi) demonstrated little tolerance of dissent over his policies. Uganda's Idi Amin regime would not have room for policy issues as the extreme unpredictability of life and arbitraries of decision making rendered policy issues obsolete. Carson (2005:3) explains that Idi Amin seized power from the country's first elected head of state, Milton Obote. During his eight years in office 1971 - 1978), Amin unleashed a reign of terror. He expelled 70000 Asians from Uganda and confiscating their land and property. He turned on his fellow Africans. Under his order and occasionally under his personal supervision, Amin`s troops killed over eight hundred thousand Ugandans, including some of the country's most prominent political, academic and intellectual leaders. Among them a chief justice of the supreme court, a vice-chancellor of the then only university (Makerere University), a foreign minister and dozens of other political leaders and businessmen. Egulu and Ebanyat (2000: 7- 8) argues that Ugandans of Asian origin had their properties and businesses expropriated and reallocated to Ugandans of African origin.

The distribution system for agricultural inputs broke down, the infrastructure for marketing and processing produce collapsed, prices dropped and the whole economy went spiraling downwards. Farmers were no longer paid for produce as the marketing boards for cotton and coffee collapsed after the government borrowed money from these institutes. The state extension system declined rapidly as the economic situation deteriorated, law and order broke down across the nation as all sectors of the economy and administration declined. George (2004; 4) points out that whilst Amin redistributed property expropriated from Asian entrepreneurs, the Ugandan economy was in a state of deterioration. The Ugandan state had failed as manager, facilitator and catalyst for development. To compound the problem it was not only expropriating land; it was also expelling entrepreneurs. Economic dimension of collapse, stagnation with redistribution became Amin's singular impact on the decline of the Ugandan economy and the collapse of the Ugandan state as a result of the militarization of politics. George $(2004 ; 1)$ argues that the Idi Amin era demonstrates how autocratic politics and policy process may be used by regimes "to consolidate illiberal governance; thus perpetuating the colonial disorder".

Mazrui (1980:53) argues that Idi Amin converted the whole world into a stage, trying to force some old imperial myths through the exit door such as the myth of Western invincibility was receiving severe knocks from Amin's sustained strategy of irreverence, and to bring in new defiant myths of black assertiveness through defiance by the expulsion of 
British Asians and the nationalization of some British firms and property. He concludes that for much of the Third World, Idi Amin had that profoundly dialectical quality of heroic evil and the West was quite clear in its verdict-the man was evil and should disappear from the scene as soon as possible; that whether one applauded the heroism or lamented or denounced the evil depend upon one's priorities. Carson, (2005:4) explains that Obote unleashed a new round of retribution and bloodletting against his previous political adversaries and remnants of Idi Amin's army. In three years he was able to create nearly as much havoc as Amin by butchering and massacring nearly six hundred thousand people, leaving piles of skulls and decomposing bodies in a part of the country called Luwero triangle. George $(2004 ; 3)$ states that Obote abandoned the independence constitution of 1962. This constitutional arrangement or experiment represented an attempt to manage Uganda's cultural pluralism by allowing a "measure of decentralization dispersal of power among predominant ethnic groups". In Obote's view such an experiment served to "impinge directly on his ability to consolidate state power". George $(2004$; 4) observes that Obote, Uganda's first post-independence and civilian ruler, began the process of gradually disintegrating civilian institutions of statehood, and instead opted for a greater role to be played by the military in state making. That is, military power became both integral and indispensable to Obote's rule. As a result when the army led by Amin became too powerful to Obote needed to build a countervailing force. Obote thus, "downgraded civilian institutions of legitimation and created conditions for Amin's overthrow". This process however was to form the backdrop to Amin's military coup of January 1971.

Egulu and Ebanyat (2000:9) observe that policy formulation in Uganda has historically been dominated by central government, while the beneficiaries were only involved during implementation. When the National Resistance Movement came to power, they jettisoned the previous top-down approach, introducing a structure that enabled all relevant stakeholders to contribute to the process.

Carson, (20005:4) explains that 1986 saw Museveni - a popular, charismatic and a genuine reformer engineering and guiding Uganda`s early transformation by pursuing a blend of economic, political and social policies ensuring an end to bloodshed and violence, and consolidating his authority over several rival political groups, bringing an end to ethnic killings and violence. Political policies ensured that peace prevailed in Uganda and this primarily gained him popularity and support. He strategically instituted one of the first successful military demobilization programs in Africa courtesy of the US, Germany and World Bank support. George $(2004 ; 1)$ writes of Museveni as a reformist leader who began to reconstruct the fallen state, but in the process openly rejected and by 2004 continued to reject the multiparty or liberal democratic model; choosing instead to focus on the economic dimension of state rehabilitation. George $(2004 ; 5)$ states that his programme emphasized "democracy, security, national unity, and the restoration of the economy". In so doing the regime was preparing and chartering the way for Uganda's reintegration into the realm of the world politics and global economics. The state's role was to be that of constructive participant, thus breaking with the common stereotype of irresponsible leadership, increased marginalization, underdevelopment and the perennial suffering of Ugandans. Carson, (2005:4) points out that Museveni was applauded and financially supported by Global Financial Institutions ( World Bank and the International Monetary Fund) for demonstrating political courage by restoring the property rights - returning shops, houses, hotels and large agricultural estates to the Asians expelled by Idi Amin. George (2004: 6) comments that the results of responding so adequately and efficiently have thus far been phenomenal as his embrace of market economics, responsible and effective underpinned by substantial respect for political and civil liberties, has "helped turn into a star performer the basket case Uganda became during the nightmare years of Idi Amin Dada and his successor, Milton Obote. The country has managed to sustain an annual growth rate of between 6 and $7 \%$ thereby rendering this former jewel of British East Africa respectable even among today's Tigers of Asia". George (2005: 6) points out that foreign investors have been coming in increasing numbers as Museveni sticks to his reforms of liberalization and privatizing the economy. Museveni has also returned expropriated properties and welcomed back South Asians who were expelled by Idi Amin's programs of the 1970's. According to Carson, (2005:4) Museveni boldly adopted and skillfully modified and embraced at his own time a major IMF economic reform program at a time when the GFIs were facing stern criticism in many parts of Africa. When the political factors such as the ruling party and the State/government apply apt policy and appropriate policy process a nation stands to benefit in its international relations as well. A fair example is the case of South Africa. Roux, (2000: ) points out that South Africa is an example of a developing African country, which since 1994 has re-entered the global arena. South Africa, for example: took up membership of, amongst other organisations: the United Nations, the European Union (EU), the Commonwealth and the Organisation for African Unity (now the African Union), South Africa was also able to obtain access to funding by the World Bank and the International Monetary Fund (Thornhill 2000: 2), and obtained access to grants from various donor organisations such as the European Union, the Dutch government, USAID, AUSAID, the Open Society, the Ford Foundation and the Kellogg Foundation. These international organisations and agencies, in various ways, set the standards against which national policy formulation can be 'benchmarked', although they cannot formulate national policy as such. 
In cases where the head of state and cabinet are committed to change and engage in effective policy processes the gains are many. Carson (2005:4-5) says that worth noting here is that Museveni was able to improve the human rights record by setting free journalists, opposition politicians and political prisoners incarcerated by the previous regimes as well as those his own regime had detained. Carson, (2005: 5) He further explains that Museveni empowered a constitutional commission to engage the nation on the nature of a democratic government they wanted, drafted a constitution and ensured a secret ballot system under international supervision that resulted in a broadly based representative government put in place. George $(2004 ; 6)$ observes that Museveni's social initiatives have also won him much respect and admiration as a responsible and effective leader. An example of this is his decision and strategy to tackle head-on Uganda's dire plaque of HIVIAIDS. It is arguable that Uganda's strategy of prevention and protection is the best in Africa, and that its success measures well against international best practices and standards. For example, one hospital experienced a drop in HIV-infected pregnant young women from $26 \%$ in 1992 to $9 \%$ in 1996 . Carson (2005:5) observes that Museveni recognized the devastating effects of HIVIAIDs in Uganda and became one of the major African leader to openly speak out about the dangers of AIDs and ensured the state opened up to the international community to assist Uganda fight the pandemic in areas of prevention campaigns, medical therapies, use of niviriprine for the prevention of mother to child transmissions. Zimbabwe's Robert Mugabe has been trotting and continues to race along popular policies (inspired by populism). That is as long as a policy finally yields more votes for his ZANU PF party, he has no problems with that. Loyalty to the party is most important for parliamentary and cabinet posts. Those who develop dissent views will not make it in next round of primary elections. Populism has always been behind Mugabe's social policies: Education and health were free after Uhuru (1980) and for a decade Zimbabwe had characteristics of welfare state. Mugabe's land policy today is loaded with rhetoric and militancy but the truth is that it rests on political populism meant to lure more votes in presidential elections and all ministers and parliamentarians (except those of the opposition) are rallying behind the Land Policy.

Thomson (2000:205) refers to Zaire as 'Mobutu's vampire state' describing how in Zaire 'self-interested extraction became both an art form and end in itself'. Mobutu is described as megalomaniac, who believed that only he could guarantee national cohesion (McNulty 1999:54, 59). Filatova (2000:14) describes Zaire as a 'personally appropriated state' noting that during the 1980s Mobutu's wealth was estimated to be about the same sum as the whole national debt. Bayart (1993:87) meanwhile, notes that Mobutu was rumoured to control between 17 and 22 percent of the national budget for his personal use. Acemoglu, Verdier and Robinson (2004:169) Mobutu exercised systematic ethnic favouritism by ensuring that his tribesmen (the Ngbandi) held offices in government and by 1990 they occupied 46\% of the officer corps, $34 \%$ of diplomats and 19\% were members of the MPR central committee. Acemoglu, Verdier and Robinson (2004:169) Mobutu allowed a lassize-faire policy only in the mercantile affairs of only those inner core persons with special close kinship, ethno- regional or political ties to him - the 'presidential brotherhood' or the 'untouchables'.

These examples fit in quite well with Grindle and Thomas (1991:37) who observe that policy elites are politicians and party leaders personally loyal to the state president, committed to a political party and specific goals of a regime. The Colombia 1966 case is a good example of political factors positively influencing policy processes in a developing country. According to Grindle and Thomas (1991:85) the president was pro the revival of the institution for data collection analysis and its inclusion in national policy decision making. He facilitated the interaction between policy makers, the advisory agency, the national planning agency, technocrats, important officials within the bureaucracy and influential members of the society. Thus the government, influential individuals and groups in society were united on policy matters. There is no doubt that political factors particularly the nature of governance influences participation in policy processes in developing countries.

\section{Policy Process as a Political Tool}

Political factors influence the policy process in the developing countries by way of converting it into a political tool. This means that policy process serves to keep the political elite in power, repress the opposition, and further its own interests and other forms of flattering the electorate. According to Grindle and Thomas (1991:101) observes that decision makers are concerned about how particular decisions will affect the conditions that sustain the regime in power by even excluding from discussion policy matters that impose heavy costs on important groups in society. Grindle and Thomas (1989:226) use cases of Mali, Kenya and Ghana to demonstrate how policy processes have been used in matters of political stability, containing the opposition and boosting political support, "Policy reform options were assessed in terms of how reaction to them would affect the longevity of the regime in power or the particular leadership wielding authority" (Grindle and Thomas 1989:226). Grindle and Thomas (1989:226, 1991:101) note that in Mali, project sites were placed near the border with Upper Volta to uphold its presence there and in another used project sites to keep a grip on the people's 
political loyalty. In the Philippines, government gave low priority to agrarian reforms meant to weaken the insurgent National Peoples' Army because the same reforms would weaken the governments' support base. Acemoglu, Verdier and Robinson (2004:169) point out that in Zaire Mobutu implemented that divide-and-rule/policy creating an environment in which any person or group could be rewarded or punished separately. They stress that such a policy strategy ensured that individuals in public office were totally dependent on him for selection and maintenance of power. By frequently rotating government posts, he managed to maintain uncertainty and vulnerability - thus playing the role of big chief bestowing favours on his subjects based on personal discretion.

Jomo Kenyatta in Kenya used the policy of centralization to ensure his tribal base enjoyed a lot of benefits. By 1970 95\% of the development budget was controlled from Nairobi. Thus administrative and development policies were used to settle political scores in that Kenyatta's regime was sustained. Acemoglu, Verdier and Robinson (2004:164) illustrate that inefficient transfers and policies in many parts of Africa notably Ghana and Zambia reflected that policy process enable the transfer of resources from the population to the ruling groups, while at the same time ensuring their political survival. In their view, the nexus was of inefficient policy served to create an environment where any group that became politically mobilized against the rules could be punished, while those that remained loyal were rewarded. Acemoglu, Verdier and Robinson (2004:164) The Ghanaian government heavily taxed cocoa producers, while at the same time subsidizing their inputs of seeds and fertilizers. These subsidies were allocated selectively as a potential reward for not attempting to change the status quo. They also argue that the exchange rate was kept overvalued because then the government could allocate or withhold valuable rations of foreign exchange in order to guarantee support. Grindle and Thomas (1991:102) observe that Ghana's policies on devolution had to be cautiously handled lest they upset forces sustaining the regime such as cocoa farmers and urban elites. Corkery, Land and Bossuyt (1997:14) remark that the Ghana case makes the point that the country at independence was relatively better endowed than most other African countries in terms of its institutional capacity for policy management. However, this capacity could not be sustained in the 1960's and 1970's when the acceptance of, and support for, a rational approach to policy formulation were seriously undermined by the combined effects of political instability and economic decline. Existing institutions decayed; the scope for wider participation in policy-making declined, and a tremendous exodus of skilled people took place. They note that in the 1980s the Government sought to create a general institutional environment for policy formulation which would be more conducive to wider consultation. Major structural changes were introduced in the functioning of the state machinery. The changes centred on programmes meant to decentralise government and to increase popular participation. Corkery, etal (1997:15) write of Ghana restructuring the ministerial structures and giving ministries the capacity to coordinate policies. These structural changes gradually allowed for a more participatory approach to policy formulation to emerge. Increased political stability helped in the need for some cost recovery policy in education was recognised by the National Consultative Committee for over a decade before government felt strong enough to take action. This indicates that political stability was still perceived to be a fragile plant. Even when the policy was introduced, it was the externally promoted and supported Economic Reform Programme which was the main catalyst for action on this sensitive issue. Economic policies meant to improve the economy were used to legitimize the government in Korea. Water management reform requiring fee increases risked negative political reaction in India and had to be reconsidered. Thus policy process is on one side influenced by political factors and on the other it is used as a political weapon. Grindle and Thomas (1991:101) remark that on such situations regime maintenance becomes the single most important factor in explaining the perpetuation of economically irrational development policies. For more than thirty years Mugabe's policies of centralization kept the Ndebeles in Matabeleland economically weaker thus easier to control politically. The revenue generated at Beitbridge, Victoria Falls, the electricity generated at Victoria Falls and the tourism that has been thriving there did not in any way benefit the region lest they become too powerful for the government. The long overdue Zambezi -Bulawayo water pipeline was shelved on numerous occasions because it could have facilitated rapid industrialization for Bulawayo the stronghold of the Ndebele tribe. Indeed policy processes have been used for repression/settling a political score. The ZANU-PF government regularly especially towards presidential and parliamentary elections pronounces its intentions to embark on the Zambezi- Bulawayo water pipeline project and a dam project at the Shangani - Gwai confluence. There is talk of government ordering the decontrol of prices at present. Those politically erudite can see that Mugabe is abandoning trade liberalization policy in favour of what pleases the electorate for presidential elections. Thus policy processes are profoundly influenced by political factors. Gulhati (1990:1150) describes how Tanzania's Julius Nyerere was able to use his authority to further his ujama ideology in policy processes. Nyerere dominated the policy process in rural development policies. Through the policy process he was able to move Tanzania back to the egalitarian society thus abandoning "mainstream capitalist and Marxian doctrines and began to articulate an original ideology and philosophy" (Gulhati 1990:1149). Nyerere was a charismatic leader who did his best to come up with an original and African brewed approach to development. One may note that in developing countries, nature/person of the ruler plays an 
important role in determining policy process. Corkery, etal (1997:15) point out that Tanzania enjoyed relative political stability, its institutional capacity to formulate policy was highly constrained. For most of the period since independence, Tanzania had a single party system with a constitution that established the supremacy of the Party (Chama Chamapinduzi Party - CCM) in the national policymaking. The Party had a highly organised structure from the local branch to the national level. It embraced a number of mass organisations which participated in the deliberations at various levels. Corkery, etal (1997:15) further note that this was sufficient to provide a genuine basis for consultation with intended beneficiaries. Even before the end of the one-party state, some changes had been introduced into government. For example, as early as 1984, local government was re-established as part of a drive towards more efficient role division in which local authorities financed and managed primary education through, for instance, the collection of parents' contributions. It is not clear, however, to what extent these authorities played a direct role in policy formulation. Another change was the establishment of a Policy Unit in the Cabinet Secretariat of the President's Office and of parallel Policy Analysis and Review Units in the Prime Minister's Office and in the Civil Service Department. While these units were designed as 'think-tanks' to advise policy-makers, it was difficult to find the expertise necessary to staff these units, as well as those planned in other ministries.

\section{Participation in Policy Process}

There is a close correlation between the person of the ruler and participation in policy process in developing countries. To substantiate this we have to consider the participation and to what extent the ruler allows them to influence policy. Gulhati (1990); Thomas and Grindle (1989), (1991) and Turner and Hulme (1997) concur that participation in policy process in developing countries is confined to a narrow circle. The writer believes a democratic state allows much participation in the policy process by as many parties as possible to ensure that all sections and sectors of the citizenry are represented. Turner and Hulme (1997:77) say that participants in the policy process include politicians at national, regional and local levels; economic elite groups; institutions such as the church, military and recipient groups; would-be-victims of policy, multi-lateral agencies and bureaucratic implementers. Thomas and Grindle (1991-59-67) include organized labour, the media, societal interests groups and those who look elsewhere for influence. Turner and Hulme (1997:73) argue that the agrarian peasant subsistence farmers are not involved in policy process. The writer's interest here is in demonstrating how political factors influence the participation of these (some of them) groups in the policy process. Here the writer looks at this theme without sequencing the policy process into its domain such as Policy-Making, policy implantation and policy evaluation. Hyden (1983:65,69) points out that power plays a significant role in policy making and planning and is an important political if not an economic instrument in the hands of African governments in particular and developing countries in general. Turner and Hulme (1997:76-77) indicate that policy process is a highly political process. In Malawi, "Banda became more or less the sole architect of economic policy after" (Gulhati 1990:1150). (Gulhati (1990:11150) states that policy issues were not open to public debate and distant views were not tolerated in Malawi. This therefore indicates that participation in policy process was at zero level in Malawi as all those groups of participants stated earlier on had no room at all (Turner and Hulme (1997:70), and Gulhati, (1990:1150) concur that participation in policy issues in Zambia included parliamentarians, the media, cabinet and bureaucratic, trade unions, leaders and consultations with close advisors. Involvement in policy process in Botswana according to Gulhati (1990:1150) included the president, the cabinet, the service (bureaucrats) who played a significant role as they similar interests with political elites. In Tanzania, participation in policy issues involved the state president Nyerere, some advisors, members of the National Executive Committee of the party, the public sector consisting of "a diverse group in terms of income, status and organizational allegiance (in support of ) Nyerere's ideology of ujamaa" (Gulhati 1990:1150). In Zimbabwe, the government has been taking people for granted and did not consult them on policy issues. It saw itself as an epitome of the people's wishes. In the first ever national consultative approach to issue of policy: The National Referendum (1999), Robert Mugabe got the shock of his life when the people voted against his self- centered New Constitution of Zimbabwe. The emergence of the new opposition party the MDC has forced the ZANU PF government to consult, debate in parliamentary, involve the stake holders in industry rather than unleash ill- considered policy on the people. Today in Zimbabwe, the Marriage laws, citizenship, land policy are debated. Trade liberalization, Economic Structural Adjustment, the DRC crisis, privatization and land invasions are examples of Mugabe's self-centered policies that were implemented without wide consultations and involvement of the would-be-victims and either major stakeholders like industrialists, property owners or investors. These examples indicate that political factors dictate who should be involved in policy process and to what extent they may be part of it. Those who are allowed to participate have an array of rewards coming their way. Rulers in developing countries have mastered the art of getting directly involved in the policy process as one way of ensuring longevity of power. At their disposal are policies executed by effective use of patronage and partisan clients in policy matters. Thus, 
easily "building coalitions of support for (themselves)" (Grindle and Thomas (1991:101). In order to succeed in such areas, Rein (1983:56) argues that the political leadership demonstrates its determination to execute its policies by use of trained corpse and other instruments to implement the policies thus retaining support and respect by the general public. What is worth noting is that political mobilization through policy process becomes easier as the state and its bureaucratic structures take such measures as would ensure that the policies enjoy full support of the beneficiary population. Martinussen (1997:241) says that for the political elite, security consideration and socio-political stability take precedence over aggregate economic growth. Such concerns may have played a key role in Uganda for Idi Amin, Marcos in the Philippines, Banda, Samora Machel, Jean Bertrand Bokassa of the Central African Republic and the ZANU-PF government in Zimbabwe. In Zimbabwe, the policy elites are battling to come up with political stability amidst containing and repressing the opposition, boosting political support. By being involved in policy process other political rewards such "maintaining the loyalty of important groups and appeasing powerful interests" (Grindle and Thomas (1991:101) become easier. As Martinussen (1997:248) observes public funds are used for building political support and paying accumulated social and political debts instead of promoting growth or effecting economic transformation. In Zimbabwe jobs and government posts such as cabinet posts, parliamentary nominations and the whole range of attached privileges are some of the rewards for those who defend the state's policies. Turner and Hulme (1997:73) remark that the coalition of rules, bureaucrats, urban workers, local industrialists and multi-national corporations (MNC) construct policies without the involvement of poor peasants for the following benefits: cheap food for urban workers protection of urban manufacturers, subsidized imports for commercial farmers and rents for the bureaucrats and rulers. Gulhati (1990:1153) adds that the ruler appreciates material benefits from his policy through favourable treatment for his own agricultural, industrial and other business assets. However, "he is assured of political survival through the support of the coalition" Gulhati (1990:1153). Thus political factors in policy process determine those who benefit and those who lose- those who reap and those exploited. The agrarian peasant subsistence farmers are victims of policy process they are excluded from. Turner and Hulme (1997:73) state that this category of citizens is not represented by the elites, is neglected by the nature of the state policies that maintain unduly low producer prices, determining the extraction of public revenue through tariffs on export crops or surpluses of agricultural marketing parastatals; the use of overvalued currencies; maintain low-cost food for urban dwellers; and a clear urban bias in the pattern of public expenditure. The economic and political responses of these peasant subsistence farmers to such politically influenced and unfair policy processes are effectively explained by Gulhati (1990:1153) and Rapley (1963:139) who say peasants stop producing crops whose controlled prices are unattractive and embark on more remunerated controlled or uncontrolled crops; some resort to the black market or informal markets leaving government controlled markets bare; and rural to urban migration increases. Turner and Hulme (1997:74), Gulhati (1990:1153) explain why these agrarian peasant subsistence farmers continue to remain victims of the influence of exploitative factors in policy process. The reasons advanced are that they find it difficult to organize interest groups because they are too many, diverse and scattered; the cost of lobbying are too high for them. The commercial farmers cannot provide them with the desired leadership because they (commercial farmers) are seduced by input subsidies; and the governments simply repress parties or factors that try to mobilize peasants into interest groups. These circumstances are typical in Zimbabwe during development work that citizens are normally not consulted and remain passive recipients of decisions imposed by and from central government. Health policies, Education policies, Agrarian policies and the entire economic policies in Zimbabwe have been consolidating government control and what has being implemented has been the result of a political calculus in the interest of the Zimbabwe's political elite. Gulhati (1990:1157) conclude that there is no doubt that the head of state plays a decisive role in determining the climate of policy process; as his strategic vision or lack of it can be crucial; the part he expects the civil service to play in the policy process is important and other factors such as securing compliance, reliance on patronage, his level of being corrupt or tolerates corruption play a crucial role.

\section{Conclusion}

This article has demonstrated how political factors influence policy process in developing countries. Firstly, the writer has summarized political party and the state with a focus on what they are and their roles. Political factors have been described as matters of governance/matters having to do with running the affairs of state. Secondly policy process has with possible brevity been defined as processes about decisions, being about power and policy process as on intensely political matter. Thirdly the writer explained how the nature of political leadership in a state influences policy issues in general by focusing on a few selected state heads in developing countries. Fourthly we have looked at policy process as a political tool in developing countries. The thrust has been on how state leadership may use policy process to achieve its aims such as staying in power longer, appeasing the electorate and other very important groups; and crashing that 
threatening opposition. Finally the way political factors allow for participation in policy process particularly who and to what extent they would remain involved. The rewards of involvement and non-involvement on the part of a few broad categories of citizens have been explained as well as the dynamics of keeping political and economic stability at the expense of the peasants. Policy process in developing countries is restricted to the few elite, heavily influenced by the person of the Head of State, meant to secure and prolong the longevity of political leadership. The politics of patronage silently lies behind policy process in developing countries.

\section{References}

Acemoglu, D, Verdier, T and Robinson, J. A. 2004. Kleptocracy and divide-and-rule: A model of personal rule. Journal of the European Economic Association. April - May 2(2-3) p 162 - 192.

Anderson, J. E. 1997. Public policy making. Boston Houghton. Mifflin.

Bayart,J. The state in Africa: the politics of the belly. London. Longman.

Bigsten, A and Kayizzi-Mugerwa, S. 2000. The political economy of policy failure in Zambia. Working papers in Economics No.23, May. Department of Economics. Goteborg University.

Bobs, M. Fowler, H.W. and Fowler, F.G. (ed) The Consise Oxford Dictionary of Current English (8th ed) Oxford Claredon Press.

Carson, J. 2005. A legacy in danger in Challenges and change in Uganda: presentations made at a conference held on June 2, 2005, "Uganda: An African success` past its prime?"

Clapham, C 1996. Africa and the international system: The politics of state survival. Cambridge: Cambridge University Press.

Corkery, J, Land, A, and Bossuyt, J. 1997. The process of policy formulation: Institutional path or Institutional maze? - A study based on the introduction of cost- sharing for education in three countries. European centre for development policy management.

Danziger,J.N.1998. Understanding the political world: A comparative introduction. 4th edition. New York: Longman.

Dunverger, 1964; Edmund Burke, 1790; Epstein, 1967; Gettel, 2004; Gilchrist, 2000; Howard, 1980; Maclver, 1947 ; and Morgan, 1981. All cited in Political parties. www. prr.hec.gov.pk/chapters/7785 - 1, pdf

Dye, T. R.1995. Understanding public policy. Englewood Cliff. NJ. Prentice Hall.

Dye, T.R. 1987. Understanding Public Policy._New York, Prentice Hall.

Ealau, H. and Prewitt, C. 1973. Labyrinths of Democracy. Indianapolis.

Egulu, B and Ebanyat, P. 2000. Policy processes in Uganda and their impact on soil fertility. Managing Africa`s soils No. 16 iied.

Filatova, I. 2000. Democracy versus State: the African Dilemma, in edited H. Solomon and I. Liebenberg. The consolidation of democracy in Africa. Aldershot. Ashgate Publishers.

Fox, W. and Meyer, I, H. 1995. Public Administration Dictionary. Juta. Cape Town.

Grindle, M and Thomas, J.W. 1989. Policy makers, policy choices, and policy outcomes: The Political economy of reform in developing countries. Policy Sciences 22.

Grindle, M. and Thomas, J.W. 1991. Public Choices and Policy Change: The Political Economy of Reform in Developing Countries. USA. John Hopkins University Press.

Gulhati, R. 1990. Who makes economic policy in Africa and How? World Development, Vol. 18, No. 8.

Hyden, G. 1983. No shortcuts to progress: African development management in perspective. London. Heinnemann.

Lawson, K. 1997. The human polity. $4^{\text {th }}$ edition, Boston. Mufflin Co.

Martinussen, J 1997. Society, State and Market: A guide to competing theories of development. London. Zed books Ltd.

Mazrui, A. A.1980. Between development and decay: Anarchy, tyranny and progress under Idi Amin. The World Quarterly, Vol. 2 No 1, January $\mathrm{p} 44-58$.

McGrew, A. 1992. The Third world in the new global order, in edited T Allen and A Thomas. Development and poverty in the 1990s. Oxford: Oxford University Press. 255 - 272.

McNulty, M. 1999. The collapse of Zaire: implosion, revolution or external sabotage? The Journal of Modern African studies. $37(1)$ p 53 82.

Potter, D. 1992. The democratization of Third World States in Development and poverty in the 1990s, edited by T Allen and A Thomas, Oxford. Oxford University Press.

Ranker, L., van de Walle, N, and Mulaisho, D. 1999. "Aid and reform in Zambia: Country Case Study" World Bank programme on Aid and Reform in Africa, WB homepage.

Ranney, A.1986. Political Science and Public Policy. Chicago Markhan Publishing Company.

Ranney, A. 1987. Governing: An introduction to political science. New Jersey: Prentice Hall.

Rapley, J. 1996. Understanding development: Theory and practice.

Rein, M. 1983. From Policy to Practice. New York. ME. Sharpe.

Roux, N.L. 2000.Public policy-making and policy analysis in South Africa amidst transformation , change and globalisation: views on participants and role players in the policy analytic procedure. Journal of Public Administration, Vol. 37 No 4 December.

Thomas, A. and Potter, A.1992. Development, capitalism and the nation State, in edited by T. Allen and A. Thomas development and poverty in the 1990s, Oxford, Oxford Press.

Thomas, G. 1992. International NGO Global governance and social policy in the UN system. New York. UN.

Thomas, J.W. and Grindle, M.S. 1990. After the Decision: Implementation Policy Reform in Developing countries World Development 
Vol. 18. No.8.

Thomson, A. 2000. An introduction to African politics. London. Routledge.

Thornhill, C. 2000. Globalisation/internationalisation. Paper presented at a MPA International Administration seminar.University of Pretoria. Pretoria.

Turner, M. and Hulme, D.1997. Governance, Administration and Development: Making the state work._London. MacMillan Press. 